\title{
Effectiveness for hypertension educational package on knowledge, attitude and lifestyle practices among adults at risk in selected urban community, Bangalore
}

\author{
Ms.Rammuanpuii Paihte \\ Lecturer, College of Nursing, \\ Dayananda Sagar University, Bangalore
}

\author{
Dr.Dinesh Selvam \\ Dean of Studies, Medical and Paramedical \\ Dr. Mohan's Diabetes Education Academy, Chennai
}

\section{ABSTRACT}

Introduction and Objectives: High blood pressure is a common condition in which the force of the blood against your artery walls is high enough that it may eventually cause health problems, such as heart disease. Blood pressure is determined by the amount of blood your heart pumps and the amount of resistance to blood flow in your arteries. The more blood your heart pumps and the narrower your arteries, the higher your blood pressure. Most of the time, no cause of high blood pressure is found. This is called essential hypertension. High blood pressure that is caused by another medical condition or medicine you are taking is called secondary hypertension. Normal blood pressure at rest is within the range of $100-140 \mathrm{mmHg}$ systolic (top reading) and $60-90 \mathrm{mmHg}$ diastolic (bottom reading). High blood pressure is said to be present if it is persistently at or above 140/90 $\mathrm{mmHg}$.

The prevalence of hypertension ranges from $20-40 \%$ in urban adults and $12-17 \%$ among rural adults. The number of people with hypertension is projected to increase from 118 million in 2000 to 214 million in 2025 , with nearly equal numbers of men and women. Comprehensive hypertension management should focus not only on reducing the blood pressure, but reducing the cardiovascular risk by lifestyle measures, lipid management, smoking cessation, and regular exercises. The objectives of the study were: To identify the adults at risk for hypertension in selected urban community and to assess the effectiveness of Hypertension Educational package on knowledge, attitude and life style practices among adults at risk.

\section{Methods:}

Pre- experimental - one group pre-test post-test design was adopted to assess the knowledge, attitude and life style practices among adults at risk. An educational package was developed focusing on the knowledge, attitude and lifestyle practices regarding hypertension.

\section{Conclusion:}

The assessment of knowledge, attitude and life style practices regarding hypertension among adults at risk revealed that the overall mean difference score for knowledge was 9.06. Mean difference score for attitude was 29.28 and for life style practices was 4.56. The Mean Score difference was significant and hence, the hypertension educational package was effective in improving knowledge, attitude and lifestyle among adults at risk.

\section{Key words}

Knowledge, Attitude, lifestyle practices, adults at risk.

\section{INTRODUCTION:}

Hypertension (HTN) or high blood pressure, sometimes called arterial hypertension, is a chronic medical condition in which the pressure in the arteries is elevated. This requires the heart to work harder than normal to circulate blood through the blood vessels. Blood pressure is summarized by two measurements, systolic and diastolic, which depend on whether the heart muscle is contracting (systole) or relaxed between beats (diastole) and equate to a maximum and minimum pressure, respectively. Normal blood pressure at rest is within the range of $100-140 \mathrm{mmHg}$ systolic (top reading) and 60$90 \mathrm{mmHg}$ diastolic (bottom reading). High blood 
pressure is said to be present if it is persistently at or above 140/90 $\mathrm{mmHg}$.

The World Health Organization (WHO) is finalizing a set of nine voluntary global targets that will help in reducing non-communicable diseases (NCDs), particularly hypertension which is a major contributor to cardio-vascular diseases

Hypertension is classified as either primary (essential) hypertension or secondary hypertension; about 90$95 \%$ of cases are categorized as "primary hypertension" which means high blood pressure with no obvious underlying medical cause. The remaining $5-10 \%$ of cases (secondary hypertension) is caused by other conditions that affect the kidneys, arteries, heart or endocrine system

High Blood Pressure or Hypertension is one of the most important preventable causes of premature death worldwide. Even a blood pressure at the top end of the normal range increases the risk. Many who are affected feel no discomfort until a medical crisis i.e. a heart attack, the rupture of a blood vessel in the brain or a stroke - strikes. As a consequence, high blood pressure is often called the "Silent Killer"

\section{OBJECTIVES:}

1 .To identify the adults at risk for hypertension in selected urban community.

2. To assess the pre-test knowledge, attitude, lifestyle regarding hypertension among adults at risk in selected urban community.

3. To assess the post-test knowledge, attitude, lifestyle regarding hypertension among adults at risk in selected urban community.

4. To compare the pre-test and post-test knowledge, attitude, lifestyle regarding hypertension among adults at risk in selected urban community.

5. To correlate knowledge with attitude and life style regarding hypertension among adults at risk in selected urban community.

6. To associate the pre-test score of knowledge, attitude, and lifestyle regarding hypertension among adults at risk with their demographic variable.

\section{MATERIALS AND METHOD:}

\section{Research design}

Pre-experimental, one pretest, posttest design

\section{Variables:}

\section{Dependent variables}

Knowledge, attitude, lifestyle practices on hypertension among adults

\section{Independent variable}

Hypertension educational package

\section{Demographic variables:}

Demographic Performa of adults consists of age, sex, educational status family income, religion, occupation, type of work, marital status, no of children and history of any health problems.

\section{Setting}

The study will be conducted at Kengeri Uppanagara, Bangalore urban district

\section{Population:}

All the adults identified at risk for hypertension.

\section{SAMPLING TECHNIQUE}

Non Probability-Purposive sampling technique

\section{DESCRIPTION OF THE INSTRUMENT:}

The structure interviewed questionnaire was prepared by the investigators based on the extensive review of literature, expert opinion and investigators personal experience. It consists of 5 sections of literature, expert opinion and investigators personal experience. It consists of 5 sections.

Section-A Check list to identify adults at risk.

Section-B Demographic variables of the subject.

Section-C It consists of 24 structured interview questionnaire for knowledge.

Section-D It consists of 20 statements for attitude. 
Section $-\mathbf{E}$ It consist of 10 structured checklist for lifestyle practices.

\section{PROCEDURE OF DATA COLLECTION}

After obtaining the official permission from the authorities of BBMP and primary health centre and informed consent from the samples, the investigator personally collected the data in the following phase.

\section{Phase1:}

The investigator identified the adults at risk for Hypertension in the urban community using checklist.

\section{Phase2:}

The investigator assessed the pre-test knowledge, attitude, lifestyle practices among adults at risk.

\section{Phase3:}

The investigator administered Hypertension educational package, causes, sign and symptoms, risk factor, management and prevention of Hypertension using flash card and pamphlets.

\section{Phase4:}

The investigator assessed the post-test knowledge, attitude and lifestyle practices among adult after one week of Hypertension educational package.

\section{RESULTS}

The total population of adults were 596 out of which 86 were assessed to be adults at risk and the prevalence rate was $(14.4 \%)$.

In the pre-test, the adults at risk for hypertension $33(55 \%)$ had inadequate knowledge, whereas $27(45.0 \%)$ of them had moderately adequate knowledge and none of them had adequate knowledge, 29(48.3\%) had unfavourable attitude, $31(51.77 \%)$ had moderately favourable attitude and none of them had favourable attitude .32(53.3\%) had poor lifestyle, 28(46.7\%) had average lifestyle and none of them had good lifestyle

In the post test, the adults at risk $55(91.7 \%)$ of them had moderately adequate knowledge, 5(8.3\%) had adequate knowledge whereas none of them had inadequate knowledge, $18(30.0 \%)$ had moderately favourable attitude and 42(70.0\%) had favourable attitude. $60(83.3 \%)$ had good lifestyle, 10(16.7\%)had average lifestyle and none of them had poor lifestyle.

The $\mathrm{t}$ value was found to be 34.42 for knowledge, 23.78 for attitude, and 11.60 for lifestyle practices respectively and it was highly significant at $5 \%$ (i.e., $\mathrm{p}<0.05)$ level, it shows that the learning programme was effective.

There is positive correlation between knowledge and attitude $(\mathrm{r}=0.349)$, between knowledge and lifestyle $(\mathrm{r}=$ $0.401)$ and between attitude and lifestyle practices $(\mathrm{r}=0.327)$ regarding hypertension educational package among adults at risk which was highly significant at $\mathrm{p}<0.05$ level.

There was significant association of knowledge with religion attitude with marital status and lifestyle practices score with children and sex.

\section{Discussion}

The present study was conducted to assess the effectiveness of Hypertension educational package among adults at risk in selected urban community. In order to achieve the objectives of the study, a pre experimental pre-test post-test design was adopted. Simple random sampling technique was used to select the samples. The data was collected from 60 respondents before and after providing the educational package. The findings of the study has been discussed with reference to the objectives, hypothesis, and with the findings of other studies.

\section{CONCLUSION:}

The learning package has a great influence on knowledge, attitude and life style practices regarding Hypertension among adults at risk.

\section{REFERENCE:}

1. Hypertension. Online cited on 29 October 1013.Available from URLhttp://en.wikipedia.org/wiki/Hypertension

2. Benzie $\boldsymbol{T}$. What Is Hypertension? What Causes Hypertension? Online cited on 29 Oct 2013. Available from:

URLhttp://www.medicalnewstoday.com/articl es/150109.php. 
3. Hypertension major contributor to avoidable deaths in India: WHO. Online cited on $29^{\text {th }}$ Oct 2013, Available from URL http://www.thehindu.com/scitech/health/hypertension-major-contributor-toavoidable-deaths-in-indiawho/article4513904.ece.
4. Lippincott Williams and Wilkins. Lippincott Manual of Nursing Practice: Judith A. Schilling Mc can, RN, MSN, Medical publishers; 2006.

Table 1 Identification at Adults at Risk for Hypertension among Adults at Risk

\begin{tabular}{|l|l|l|l|l|l|}
\hline \multicolumn{1}{|c|}{ SI. No. } & \multicolumn{1}{|c|}{ Area } & \multicolumn{1}{|c|}{ Population } & Adults & Adults at risk & \multicolumn{1}{|c|}{ Rate (\%) } \\
\hline $\mathbf{1 .}$ & $\begin{array}{l}\text { Kengeri } \\
\text { Upanagara }\end{array}$ & 3098 & 596 & 86 & $14.4 \%$ \\
\hline
\end{tabular}

Table: 2Frequency and percentage distribution of adults at risk for hypertension according to pre and posttest level of knowledge regarding hypertension

\begin{tabular}{|c|c|c|c|c|c|}
\hline \multirow[t]{2}{*}{ SI. No. } & \multirow[t]{2}{*}{$\begin{array}{c}\text { Level of } \\
\text { knowledge }\end{array}$} & \multicolumn{2}{|c|}{$\begin{array}{l}\text { Pre hypertension educational } \\
\text { package }\end{array}$} & \multicolumn{2}{|c|}{$\begin{array}{l}\text { Post hypertension } \\
\text { educational package }\end{array}$} \\
\hline & & $\begin{array}{l}\text { No. } \\
(60)\end{array}$ & $\%$ & $\begin{array}{l}\text { No. } \\
\text { (60) }\end{array}$ & $\%$ \\
\hline 1. & $\begin{array}{l}\text { Inadequate } \\
\text { knowledge }(<50 \%)\end{array}$ & 33 & 55.0 & & - \\
\hline 2. & $\begin{array}{l}\text { Moderately } \\
\text { adequate } \\
\text { knowledge (50- } \\
75 \%)\end{array}$ & 27 & 45.0 & 5 & 8.3 \\
\hline 3. & $\begin{array}{l}\text { Adequate } \\
\text { knowledge }(>75 \%)\end{array}$ & - & \begin{tabular}{|l}
-- \\
\end{tabular} & 55 & 91.7 \\
\hline Total & & 60 & 100 & 60 & 100 \\
\hline
\end{tabular}


International Journal of Trend in Scientific Research and Development, Volume 1(4), ISSN:

Table: 3 Frequency and percentage distribution of adults at risk for hypertension according to the pre and post-test level of attitude regarding hypertension.

\begin{tabular}{|c|c|c|c|c|c|}
\hline \multirow[t]{2}{*}{$\begin{array}{l}\text { SI. } \\
\text { No. }\end{array}$} & \multirow[t]{2}{*}{ Level of attitude } & \multicolumn{2}{|c|}{$\begin{array}{l}\text { Before hypertension } \\
\text { educational package }\end{array}$} & \multicolumn{2}{|c|}{$\begin{array}{l}\text { After hypertension } \\
\text { educational package }\end{array}$} \\
\hline & & No. (60) & $\%$ & No. (60) & $\%$ \\
\hline 1. & Unfavorable attitude $(<50 \%)$ & 29 & 48.3 & - & - \\
\hline 2. & Moderately favorable attitude (50-75\%) & 31 & 51.77 & 18 & 30.0 \\
\hline 3. & Favorable attitude $(>75 \%)$ & - & - & 42 & 70.0 \\
\hline Tota & & 60 & 100 & 60 & 100 \\
\hline
\end{tabular}

TABLE: 4 Frequency and percentage distribution of adults at risk of hypertension according to the pre and posttest level of life style practices regarding hypertension

\begin{tabular}{|l|l|l|l|l|l|}
\hline \multirow{2}{*}{ SI.No. } & \multicolumn{2}{|c|}{ Level of life style practices } & \multicolumn{2}{|c|}{$\begin{array}{c}\text { Before hypertension } \\
\text { educational package }\end{array}$} & \multicolumn{2}{|c|}{$\begin{array}{c}\text { After hypertension } \\
\text { educational package }\end{array}$} \\
\cline { 3 - 7 } & No. (60) & \multicolumn{2}{c|}{ No. (60) } & $\%$ \\
\hline 1. & Poor $(<50 \%)$ & 32 & 53.3 & - & - \\
\hline 2. & Average $(50-75 \%)$ & 28 & 46.7 & 10 & 16.7 \\
\hline 3. & Good $(>75 \%)$ & - & - & 50 & 83.3 \\
\hline Total & & $\mathbf{6 0}$ & $\mathbf{1 0 0}$ & $\mathbf{6 0}$ & $\mathbf{1 0 0}$ \\
\hline
\end{tabular}

TABLE: 5 Paired t-test analysis for the significance of pre and posttest knowledge regarding hypertension among adults at risk for hypertension.

\begin{tabular}{|c|c|c|c|c|c|c|c|}
\hline Sl. No. & $\begin{array}{l}\text { Aspects of } \\
\text { knowledge }\end{array}$ & Max. Score & $\begin{array}{l}\text { Mean } \\
\text { difference }\end{array}$ & $\begin{array}{l}\text { SD of } \\
\text { difference }\end{array}$ & $\begin{array}{l}\% \text { of } \\
\text { mean } \\
\text { difference }\end{array}$ & $\begin{array}{c}\text { Paire } \\
\text { d t- } \\
\text { value }\end{array}$ & p-value \\
\hline 1. & $\begin{array}{l}\text { General } \\
\text { information }\end{array}$ & 5 & 1.85 & 0.971 & 37 & 14.76 & $\mathrm{P}<0.05$ \\
\hline 2. & Causes & 3 & 1.21 & 0.66 & 40.33 & 14.14 & $\mathrm{P}<0.05$ \\
\hline 3. & Risk factors & 5 & 1.78 & 1.05 & 35.6 & 13.04 & $\mathrm{P}<0.05$ \\
\hline 4. & Signs & 2 & 0.65 & 0.68 & 32.5 & 7.35 & $\mathrm{P}<0.05$ \\
\hline 5. & Management & 5 & 2.16 & 0.94 & 42.2 & 17.82 & $\mathrm{P}<0.05$ \\
\hline 6. & Complication & 4 & 1.41 & 1.04 & 35.25 & 0.48 & $\mathrm{P}<0.05$ \\
\hline Over all & & 24 & 9.06 & 5.34 & 37.6 & 34.42 & $\mathrm{P}<0.05$ \\
\hline
\end{tabular}


TABLE: 6 Paired t-test analysis for the significance of pre and posttest attitude regarding hypertension among adults at risk for hypertension

\begin{tabular}{|l|l|l|l|l|l|l|l|}
\hline Attitude & $\begin{array}{l}\text { Max. } \\
\text { Score }\end{array}$ & $\begin{array}{l}\text { Mean } \\
\text { difference }\end{array}$ & $\begin{array}{l}\text { SD of } \\
\text { difference }\end{array}$ & $\begin{array}{l}\text { \% of } \\
\text { mean } \\
\text { difference }\end{array}$ & & $\begin{array}{l}\text { Paired } \\
\text { t-value }\end{array}$ & -value \\
\hline Over all & $\mathbf{1 0 0}$ & 29.28 & 9.70 & 29.28 & & $23.78^{*}$ & $\mathrm{p}<0.05$ \\
\hline
\end{tabular}

TABLE: 7 Paired t-test analysis for the significance of pre and posttest Level of life style practices regarding hypertension among adults at risk for hypertension

\begin{tabular}{|l|l|l|l|l|l|l|}
\hline \multicolumn{1}{|c|}{$\begin{array}{c}\text { Life style } \\
\text { practices }\end{array}$} & $\begin{array}{c}\text { Max. } \\
\text { Score }\end{array}$ & $\begin{array}{c}\text { Mean } \\
\text { difference }\end{array}$ & $\begin{array}{c}\text { SD of } \\
\text { difference }\end{array}$ & $\begin{array}{c}\text { \% of mean } \\
\text { difference }\end{array}$ & $\begin{array}{c}\text { Paired t- } \\
\text { value }\end{array}$ & \multicolumn{1}{|c|}{-value } \\
\hline Over all & 12 & 4.56 & 1.69 & 38.0 & $11.60^{*}$ & $\mathrm{p}<0.05$ \\
\hline
\end{tabular}

TABLE: 8 Correlation between knowledge, attitude and lifestyle practices regarding hypertension among adults at risk for hypertension

\begin{tabular}{|c|c|c|c|c|c|}
\hline $\begin{array}{l}\text { SI. } \\
\text { No. }\end{array}$ & Variables & Mean & SD & $\mathbf{r}$ & $p$-value \\
\hline \multirow[t]{2}{*}{1.} & Knowledge & 12.02 & 4.70 & \multirow[t]{2}{*}{0.349} & \multirow[t]{2}{*}{$\mathrm{p}<0.05$} \\
\hline & Attitude & 48.75 & 3.33 & & \\
\hline \multirow[t]{2}{*}{2.} & Knowledge & 12.02 & 4.70 & \multirow[t]{2}{*}{0.401} & \multirow[t]{2}{*}{$\mathrm{p}<0.05$} \\
\hline & Life style practices & 5.53 & 0.97 & & \\
\hline \multirow[t]{2}{*}{3.} & Attitude & 48.75 & 3.33 & \multirow[t]{2}{*}{$0.327^{\prime}$} & \multirow[t]{2}{*}{$\mathrm{p}<0.05$} \\
\hline & Life style practices & 5.53 & 0.97 & & \\
\hline
\end{tabular}

